\title{
Comparison of immunodiffusion and enzyme linked immunosorbent assay in the detection of abnormal antibodies in pigeon breeder's disease
}

\author{
C Simpson, P V Shirodaria, J P Evans, D I H Simpson, C F Stanford
}

\begin{abstract}
Aims: To compare the sensitivity of two methods for the detection of serum antibodies to pigeon faecal antigens in patients with pigeon breeder's disease. Methods: Serum samples stored at $-20^{\circ} \mathrm{C}$ from 50 patients with pigeon breeder's disease, 50 control samples from patients with other respiratory diseases, and $\mathbf{5 0}$ healthy blood donors were examined for the precipitating antibodies and IgG antibodies to antigens present in extract of pigeon droppings by immunodiffusion and enzyme linked immunosorbent assay (ELISA), respectively.
\end{abstract}

Results: Both antigen preparations of pigeon dropping extract were equally effective. A positive immunodiffusion reaction gave one or more precipitin lines and these antibodies were detected only in undiluted sera from $80 \%$ of the patients with pigeon breeder's disease. In the ELISA the sera were tested at a starting dilution of 1 in 100 because positive reactions were observed with sera from healthy blood donors at lower dilutions. All sera which gave optical density readings above 3 SD of the control value were considered to have IgG antibodies. These antibodies were detected in sera from all the patients with pigeon breeder's disease. The antibody titres were much higher in those patients who had precipitating antibodies (range 80051200 ) than those without (range 100800). The antibodies were not detected in the sera of patients with respiratory diseases or healthy blood donors by either method.

Conclusions: Antibodies to pigeon dropping antigens were detected by immunodiffusion and ELISA in sera from patients with pigeon breeder's disease but not in control sera. ELISA was a more sensitive method for detecting antibodies and therefore seems to have considerable potential as a routine technique in the serological diagnosis of pigeon breeder's disease.

Pigeon breeder's disease, a hypersensitivity pneumonititis, is caused by the inhalation of pigeon derived antigens. ${ }^{1}$ The clinical picture comprises chills, fever, cough and dyspnoea several hours after exposure to pigeons. ${ }^{2}$ The disease is associated with circulating IgG antibodies against antigens in pigeon droppings or pigeon serum. It has also been reported that the pigeon droppings are probably the principal source of the major antigens to which these patients develop antibodies. ${ }^{3}$ The circulating antibodies in the sera of these patients are usually detected by Ouchterlony's double diffusion method (immunodiffusion). ${ }^{4}$ Other methods such as immunoelectrophoresis, ${ }^{5}$ passive haemagglutination, ${ }^{5}$ indirect immunofluorescence ${ }^{6}$ and immunoradiometric assay ${ }^{7}$ have also been used. Several recent reports have detailed that enzyme linked immunosorbent assay (ELISA) has been successfully applied to the detection of antibodies to pigeon antigens in patients with pigeon breeder's disease..$^{8-10}$ One of the problems with an immunodiffusion test used in the diagnostic laboratory is that precipitating antibodies to pigeon antigens cannot always be detected in the sera of patients with a history of exposure to birds and clinical symptoms suggestive of pigeon breeder's disease. ${ }^{5}$ We therefore compared the sensitivity of ELISA and immunodiffusion for the detection of IgG antibodies to pigeon antigens in the sera of patients with pigeon breeder's disease and control groups.

\section{Methods}

Serum samples included in this study were from: (i) sera sent to our Regional Allergic Alveolitis Laboratory for a precipitin antibody test to pigeon antigens (All these patients had a history of exposure to pigeons and clinical symptoms such as fever, cough, and breathlessness suggestive of pigeon breeder's disease.); (ii) sera from other respiratory conditions which included asthma, bronchopulmonary allergic aspergillosis, asbestosis, bronchiectasis and mycetoma; and (iii) control sera from healthy blood donors.

Fifty subjects were included in each group, six women and 44 men, with a mean age as follows: (i) 45.7 years (range 14-69 years); (ii) 45.5 years (range 15-69 years); and (iii) $44 \cdot 2$ years (range 16-70 years). The subjects in the three groups were matched for sex and age within two years. The sera were collected over two years and stored in small aliquots at $-20^{\circ} \mathrm{C}$ until tested under code.

Two preparations of pigeon dropping extracts were initially used as antigens for comparison in gel diffusion test and ELISA. A commercial preparation of pigeon faecal extract was purchased from Mercia Diagnostics Ltd, Guildford, Surrey, England. The 
second extract was prepared in our laboratory by disrupting fresh pigeon faeces (obtained from a pet shop) in distilled water with glass beads. The suspension was centrifuged at 2000 $\times g$ for 10 minutes and the supernatant was further clarified by filtration through a $0.45 \mu \mathrm{m}$ filter (Millpore Corporation, Massachusetts, USA). The supernatant was stored at $-70^{\circ} \mathrm{C}$ in small aliquots and a single extract preparation was used in the gel diffusion test and ELISA throughout the study. The protein concentration of commercial pigeon droppings extract was $11.0 \mathrm{mg} / \mathrm{ml}$ and fresh extract was $10.3 \mathrm{mg} /$ ml.

\section{SEROLOGICAL METHODS \\ Precipitins}

Precipitating antibodies against pigeon dropping antigens were detected and semiquantitatively evaluated by immunodiffusion. The agar gels were prepared in $1.5 \%$ ion agar (Oxoid) in McIlvane's buffer ( $\mathrm{pH} 7 \cdot 0$ ) containing $0.2 \%$ sodium azide in $5 \mathrm{~cm}$ plastic Petri dishes (Cellcult). A cutter giving a central well $(12.5 \mathrm{~mm}$ in diameter) for serum and six peripheral wells $(4 \mathrm{~mm}$ in diameter) for antigens at a distance of $6 \mathrm{~mm}$ from the central well was used. The pigeon dropping extract used had a final concentration of $39 \mu \mathrm{g} / \mathrm{ml}$. The sera were tested undiluted and also at dilutions of 1 in 5,1 in 10, and 1 in 100 . The diffusion time was two to seven days at room temperature and the gels were observed daily for the appearance of precipitin lines. Weak reactions were further analysed after staining with Azocarmine B (Edward Gurr Ltd, London).

\section{ELISA}

The solid phase indirect ELISA used for the detection of IgG antibodies to pigeon dropping antigens was based on the method described by Voller et al. ${ }^{11}$ ELISA was performed in flat-bottom wells of a polystyrene microtitre plate (Sterilin Ltd; Middlesex, England). The optimal concentration of pigeon dropping antigens used in the ELISA was determined by chessboard titration using precipitin antibody positive sera from patients with pigeon breeder's disease and negative control sera from blood'donors. Both antigen preparations (commercial and our own) were used at an optimal concentration of $1.0 \mu \mathrm{g} / \mathrm{ml}$ in the ELISA. For coating wells of the microtitre plate, the antigen preparation was diluted in bicarbonate-carbonate buffer, $\mathrm{pH} 9 \cdot 6$, and $100 \mu \mathrm{l}$ of the dilution was added to each well for two hours at $37^{\circ} \mathrm{C}$. After five washings with phosphate buffered saline containing $0.05 \%$ Tween-20 (PBS-T), $100 \mu \mathrm{l}$ of serial two-fold dilutions of patient serum in PBS-T-BSA (bovine serum albumin) were added to appropriate wells and incubated for two hours at $37^{\circ} \mathrm{C}$. After five washes with PBS-T $100 \mu \mathrm{l}$ of goat antihuman IgG coupled to horseradish peroxide and diluted 1 in 1000 (ICN Immunobiologicals, Lisle) was added to each well and incubated for one hour at $37^{\circ} \mathrm{C}$. This was followed by five further washes with PBS-T and $100 \mu$ l of freshly prepared substrate solution ( $0 \cdot 1 \mathrm{M}$ phosphate-citrate buffer, $\mathrm{pH} 5 \cdot 0$,
$3.0 \% \quad \mathrm{H}_{2} \mathrm{O}_{2}$ and $0.4 \mathrm{mg} / \mathrm{ml}$ orthophenylenediamine dihydrochloride) was added to each well. The reaction was stopped after $20 \mathrm{~min}$ utes by adding $100 \mu \mathrm{l} 1 \mathrm{MH}_{2} \mathrm{SO}_{4}$ to each well. The optical density (OD) of the final colour was read at $490 \mathrm{~nm}$ and $410 \mathrm{~nm}$ in a dual wavelength Dynatech MR600 microplate reader.

\section{Absorption of sera}

The specificity of the ELISA was confirmed by absorption of positive pigeon breeder's disease sera (diluted 1 in 10) with either a washed pellet of pigeon droppings, or a pellet of hen droppings, or a pellet of human faeces $(30 \% \mathrm{v} / \mathrm{v})$. The absorption was carried out for one hour at $37^{\circ} \mathrm{C}$, followed overnight at $4^{\circ} \mathrm{C}$. The sera were clarified by centrifugation at $10000 \times g$ for 20 minutes at $4^{\circ} \mathrm{C}$ before testing.

\section{Results}

IMMUNODIFFUSION

Similar results were observed with the immunodiffusion test when a commercial preparation or our laboratory preparation of pigeon dropping antigens were used. Sera with precipitating antibodies gave between one and four precipitin lines after incubation of the geldiffusion dishes for four days at room temperature. The precipitin lines were only observed with undiluted sera and were not observed at serum dilutions of 1 in 5,1 in 10, and 1 in 100 even after the gels had been stained with Azocarmine B.

STANDARDISATION AND SPECIFICITY OF ELISA To determine the optimal dilution of human sera to be used in the ELISA, 18 sera positive for precipitating antibodies from patients with pigeon breeder's disease and 18 age and sex matched sera without precipitating antibodies from healthy blood donors were tested at dilutions of 1 in 10, 1 in 50, and 1 in 100. Figure 1 shows that all pigeon breeder's disease sera at 1 in 10,1 in 50, and 1 in 100 dilutions gave high OD readings. With control sera, strong and moderate reactivity was observed at dilutions of 1 in 10 and 1 in 50, respectively. The OD values at the 1 in 100 dilution were much lower; therefore, a dilution of 1 in 100, which yielded a

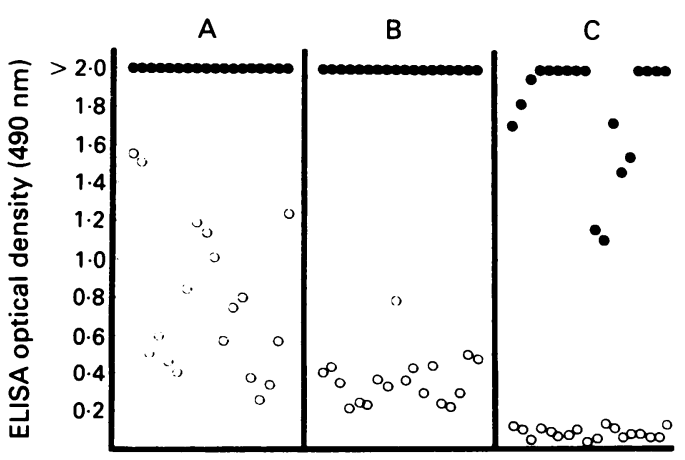

Figure 1 Optical density readings for serum IgG antibodies to pigeon dropping antigens by ELISA: (A) pigeon breeder's disease sera $(O)$ ) and control sera $(O)$ diluted 1 in 10; (B) pigeon breeder's disease sera (O) and control sera $(O)$ diluted 1 in $50 ;(C)$ pigeon breeder's disease sera ( $)$ and control sera ( $O$ ) diluted 1 in 100. 
Incidence of antibodies to pigeon dropping antigens shown by immunodiffusion and ELIS $A$ in patient and control sera

\begin{tabular}{lll}
\hline Study group & No of sera positive & $\begin{array}{l}\text { No of sera positive } \\
\text { by immunodiffusion }\end{array}$ \\
\hline Pigeon breeder's disease & by ELS A & $40 / 50$ \\
Other respiratory diseases & $50 / 50$ & $0 / 50$ \\
Blood donor controls & $0 / 50$ & $0 / 50$ \\
\hline
\end{tabular}

much lower reactivity with control sera, was used in all subsequent tests. The standardisation of the ELISA was further achieved by routinely including positive serum with precipitating antibodies from patients with pigeon breeder's disease and negative serum without precipitating antibodies from blood donors in each plate. Thus OD readings of colour change for positive serum at 1 in 100 dilution was always more than $2 \cdot 0$; at 1 in 800 dilution it was between $0 \cdot 9-1 \cdot 1$. The mean of the OD readings used as a reference was calculated from the OD values obtained from 50 normal sera at 1 in 100 dilution. This reference value of 0.082 ( 3 SD) was considered evidence of the presence of antibodies to pigeon dropping antigens. Differences in IgG antibody titres to pigeon dropping antigens were not observed when 24 pigeon breeder's disease sera with precipitating antibodies were titrated by ELISA using either a commercial preparation or our laboratory preparation of pigeon dropping extract as antigen. A standardised preparation of pigeon dropping antigen prepared in our laboratory was therefore used in all subsequent ELISAs.

The absorption of 30 positive pigeon breeder's disease sera with a pellet of pigeon droppings completely removed the positive reaction of these sera in the ELISA. However, positive reaction to pigeon dropping antigens was not removed after absorption of these sera with a pellet of hen droppings or human faeces (results not shown).

The precipitating antibodies to pigeon dropping antigens were detected by the immunodiffusion test in 40 sera from patients with pigeon breeder's disease. Antibodies were not detected in 10 sera from patients with pigeon breeder's disease, sera from patients with other respiratory diseases, and in those from healthy blood donors (table). Moreover, antibodies discovered by double gel-diffusion test were only detected when sera were used undiluted.

The IgG antibodies to pigeon dropping antigens were detected by ELISA in all 50 sera from patients with pigeon breeder's disease (table). Moreover, the highest antibody titres

Figure 2 Reciprocal titres of serum IgG antibodies to pigeon dropping antigens in patients with pigeon breeder's disease with precipitating antibodies (O), patients without precipitating antibodies (O), patients with other respiratory diseases $(\triangle)$ and control blood donors (A). were found in the sera of those patients who also had precipitating antibodies. The range of antibody titres in these patients was between 800 and more than 51200; sera of pigeon breeder's disease patients who lacked precipitating antibodies had lower antibody titres and the range was between 100 and 800 (fig 2).

\section{Discussion}

The mechanisms by which exposure to pigeons produces pigeon breeder's disease is not known. But it is generally accepted that precipitating antibodies and activated $T$ lymphocytes to pigeon material are involved in the pathogenesis of pigeon breeder's disease. ${ }^{1213}$ The presence of precipitating antibodies alone to pigeon antigens is not diagnostic of pigeon breeder's disease as these antibodies are also found in the sera of asymptomatic pigeon breeders. $^{8}$ But the presence of antibodies together with a clinical history is considered to be one of the major diagnostic criteria for the disease. ${ }^{910}$

In this study we have shown that IgG antibodies to pigeon antigens are present in the sera of patients with pigeon breeder's disease using the immunodiffusion test and ELISA. As it was difficult to obtain sera from asymptomatic members of a local pigeon racing club, only sera from symptomatic patients with pigeon breeder's disease were analysed. The pigeon dropping extract was used as a source of antigens because it is generally accepted that pigeon dropping extract contains a full "complement" of major antigens against which antibodies are formed in patients with pigeon breeder's disease. ${ }^{3}$ The commercial preparation and our laboratory preparation of pigeon dropping antigens were adequate for use as antigens in the immunodiffusion test and ELISA.

Precipitating antibodies to pigeon dropping antigens were detected by immunodiffusion test only in the undiluted sera of pigeon breeder's disease patients. Moreover, the antibodies were found in $80 \%$ of the patients' sera. These antibodies were not detected in sera of patients with other respiratory diseases or control blood donors. In the positive immunodiffusion test of pigeon breeder's disease sera one or more precipitin lines were detected. These results are similar to those reported by Elgefors $e t a l^{5}$ and Andersen $e t a l,{ }^{8}$ who found precipitating antibodies in $60 \%$ of pigeon breeder's sera and $100 \%$ of pigeon breeder's disease sera, respectively. The higher incidence observed by Andersen et al may have been due to the analysis of a small number of sera from pigeon breeder's disease patients. ${ }^{8}$

The positive reactions with pigeon breeder's disease antigens were observed in the ELISA when control sera were tested at lower dilutions, although OD readings obtained were much lower than those observed with sera from pigeon breeder's disease patients at similar dilutions. At higher dilutions (1 in 100) pigeon breeder's disease sera gave much higher OD readings than control sera. Whether positive 
reactions observed with control sera at lower dilutions are due to specific antibodies to pigeon dropping antigens or to crossreacting antibodies is not clear from the present study and needs to be further investigated.

Antibodies to pigeon dropping antigens were detected in all the sera from pigeon breeder's disease patients and all sera gave OD readings above 3 SD of the control value. These results confirm that ELISA is more sensitive than immunodiffusion in detecting antibodies to pigeon dropping antigens, and as such is of great potential as a routine laboratory technique for the serological diagnosis of pigeon breeder's disease. It was also interesting to note that the highest antibody titres were found in those patients who also had precipitating antibodies. Similar observations have been reported by Andersen et al. ${ }^{8}$ The reasons for these differences in antibody responses in patients with pigeon breeder's disease are unclear. Factors such as variation in the quantity of antigen during exposure, length of time of exposure, or influence of host factors may have a role. Studies on the genetic predisposition to produce increased concentrations of precipitating antibodies in pigeon breeder's disease patients have proved inconclusive. ${ }^{814}$ Further studies using techniques such as immunoblotting to ascertain whether antibody responses to various polypeptides of pigeon dropping antigens vary in these patients would be rewarding. Inclusion of asymptomatic patients in such a study would also help to shed light on the antibody response in patients with pigeon breeder's disease.
We thank Mr J J McAlister, principal MLSO of the Department of Microbiology and Immunobiology, and Dr M McClelland of The Northern Ireland Blood Transfusion Service.

1 Reed CE, Susman A, Barbee RA. Pigeon breeder's lung. JAMA 1965;193:261-5.

2 Fink JN, Sosman AJ, Barboriak JJ, Schlueter DP, Holmes RA. Pigeon breeder's disease. Ann Int Med 1968;68: 1205-19.

3 Edwards JH, Barboriak JJ, Fink JN. Antigens in pigeon breeder's disease. Immunology 1970;19:729-34.

4 Longbottom JL, Pepys J. Pulmonary aspergillosis: Diagnostic and immunological significance of antigens and $C$ substance in Aspergillus fumigatus. J Pathol Bacteriol 1964;88:141.

5 Elgefors B, Belin L, Hanson LA. Pigeon breeder's lung. Clinical and immunological observations. Scand $J$ Respir Dis 1971;52:167-76

6 Eade OE, Hodges JR, Berrill WT, Lang C, Lloyd RS, Wright R. Immunofluorescent antibodies in patients with bird-fancier's lung. Clin Exp Immunol 1978;32:259-62.

7 Patterson R, Wang JLF, Fink JN, Calvanico NJ, Roberts $M$ IgA and IgG antibody activities of serum and bronchoalveolar fluid from symptomatic and asymptomatic choalveolar fluid from symptomatic and asymptomatic

8 Andersen $\mathrm{P}$, Christensen KM, Jensen BE, et al. Antibodies to pigeon antigens in pigeon breeders. Eur $J$ Respir Dis 1982;63:113-21.

9 Bourke S, Anderson K, Lynch P, et al. Chronic simple bronchitis in Pigeon fanciers. Chest 1989;95:598-601.

10 Sandoval J, Banales JL, Cortes JJ, Mendoza F, Selman M, Reyes PA. Detection of antibodies against avian antigens in bronchoalveolar lavage from patients with Pigeon breeder's disease: usefulness of enzyme-linked immunosorbent assay and enzyme immunotransfer blotting. J Clin Lab Analyt 1990;4:81-5.

11 Voller A, Bidwell DE, Barlett A. Enzyme immunoassays in diagnostic medicine. Bull WHO 1976;53:55-65.

12 Boyd G, McSharry CP, Banham SW, Lynch PP. A current review of pigeon fancier's lung. Clin Allergy 1982;12 (suppl):53-9.

13 Costabel V, Bross KJ, Marxen J, Matthys H. Tlymphocytosis in bronchoalveolar lavage fluid of hypersensitivity pneumonitis. Chest 1984;85:514-8.

14 Rittner C, Sennekamp J, Vogel F. HLA-B8 in pigeon fancier's lung. Lancet 1975;ii:1303. 